UDC: 579.676

\title{
NOVEL FUNCTIONAL FOOD FOR PREVENTION OF NON-COMMUNICABLE DISEASES
}

\author{
V. V. Bati, N. V. Boyko
}

Educational Institution "Uzhgorod National University" Research and Training Center of Molecular Microbiology and Mucosal Immunology Medical Faculty 1, Narodna Sq., Uzhgorod 88000, Ukraine e-mail: victoria.bati@uzhnu.edu.ua

Bati V. V., Boyko N. V. Novel functional food for prevention of non-communicable diseases. Studia Biologica, 2019: 13(1); 71-84 • DOI: https://doi.org/10.30970/sbi.1301.589

This work is devoted to a coverage of our new approaches in a design of functional food products (FFPs). In our opinion, the necessary requirement for the construction of such new FFPs is a use of sequenced microorganisms with (clinically) proven beneficial biological properties (as probiotic components or microbial fermentation, starters of fermentation) and edible plants including berries which in turn are a source of prebiotic and biologically active substances, whose content largely depends on the conditions of cultivation and methods of technological food processing.

We have developed and proposed for production of FFP with the expected (prognostic, predefined) specific properties. This is a sour milk drink consisting of pre-selected with biological properties established in vitro and in vivo $[3,4]$ the probiotic composition of authors strains of microorganisms Lactobacillus casei ATCC 27139, Lactobacillus plantarum JCM 1149, L. casei MGB63-1, L. plantarum and prebiotic component presented by extracts (freshly dried juice) of cherry plum, blueberries, pomegranate, persimmon and cornelian cherry. These plant extracts (berries) are rich in biologically active substances (BAS) and are characterized by the ability to modulate the microbiocenosis of human intestine causing its correction towards a reduction of pathogenic and opportunistic pathogens and growth of beneficial microorganisms, antioxidant and antiinflammatory properties $[13,26]$.

Functional product possesses antibacterial activity against pathogens of the intestinal infections of Escherichia coli (EPEC), Salmonella enterica subspecies enterica serovar Enteritidis (S. enteritidis), Shigella dysenteriae until complete inhibition of their growth after 72 hours of co-cultivation. Also, an essential antibacterial activity of sour milk beverage with blueberry extract was established in relation to a number of the opportunistic microorganisms such as Morganella morganii, Staphylococcus aureus,

(C) 2019 V. V. Bati et al. Published by the Ivan Franko National University of Lviv on behalf of Біологічні Студії / Studia Biologica. This is an Open Access article distributed under the terms of the Creative Commons Attribution License (http://www.budapestopenaccessinitiative.org/ and Creative Commons Attribution 4.0 License), which permits unrestricted reuse, distribution, and reproduction in any medium, provided the original work is properly cited.

ISSN 1996-4536 (print) • ISSN 2311-0783 (on-line) • Біологічні Студії / Studia Biologica • 2019 • Том 13/№1 • С. 71-84 
methicillin-resistant S. aureus (MRSA), Enterobacter cloacae. The same effect was observed for the E. coli ATCC 25922 collection strain. The dairy drink with cherry plum showed antibacterial activity against strains of microorganisms: E. coli ATCC 25922, EPEC, S. aureus, MRSA, S. enteritidis, S. dysenteriae, Pseudomonas aeruginosa, Enterobacter cloacae. The dairy product with blueberries was suppressed by: P. aeruginosa, M. morganii, Listeria monocytogenes, S. enteritidis, S. dysenteriae, S. aureus, E. coli ATCC 25922, EPEC, MRSA, and also comensal strains of E. coli 058 and E. coli Schaedler's. However, it has been noted that a suppressive action was increased with the addition of native extracts (blueberries / cherry plum / dill / pomegranate). Cherry plum and pomegranate had a greater antagonistic effect on Klebsiella pneumonia and K. oxytoca. At the same time, a new generation FFP stimulated growth of representatives of useful microbiota.

Keywords: functional food; personified approach; intestinal microbiota; antimicrobial activity; anti-inflammatory activity; plant extracts; probiotics

\section{INTRODUCTION}

Modern studies indicate that human microbiome is the most accurate (sensitive) indicator of it's physiological health. According to experts from the World Health Organization (WHO), the health of human depends on nutrition as the most important factor regulating human microbiome [11]. Changes in microbiota are closely related to functioning of all macroorganism systems and associated with metabolic diseases [8], including obesity, type 2 diabetes, cardiovascular diseases, etc. Today, noncommunicable diseases (NCDs) rank first in the mortality of the population without exception of all countries of the world.

The most important factor that regulates intestinal microbiota of human is nutrition [10]. Today, food is considered not only as a set of essential nutrients for growth and development, but as an important component of optimal human health [9]. For a correction of human microbiota, it is often recommended to prescribe pro-, pre- or synbiotics. However, their use does not lead to a prevention of the NCD's due to a lack of probable criteria for assessing their efficacy in clinical trials and sporadic and non-personified use [18].

In in vivo studies, researchers found that cow's non-fermented milk could cause an inhomogeneous (negative) reaction to the intestinal microbiota. However, the use of fermented cow's milk, such effects were absent due to fermentation [24].

The most promising method of designing innovative functional food products of vegetable origin, and primarily fermented FFP, with their proven ability to exert a positive influence on human health is to carefully select an original microbial leaven, to obtain complete reliable information on a course of enzymatic processes and the ability of their components to directed correction of intestinal microbiota [18] (oppression of conditionally pathogenic representatives of microbiota and neutral or stimulatory action against beneficial microorganisms) and presence of proven clinical anti-inflammatory properties.

Many studies have shown that lactic acid bacteria and species of Bifidobacterium can produce the bioactive compounds such as conjugated linoleic acids (CLAs) [27], neurotransmitters [16], Ahr-ligands [28], polyphenols [21], iron absorbers [7, 29], vitamins [1, 20], Short-Chain Fatty Acids (SCFA) [22], and antioxidants [2]. Future studies will certainly identify the additional functions that these bacteria can provide [8].

According to classical views [13, 19], functional foods include food and beverages whose use leads to regulation of a number of physiological processes of the human body to prevent the emergence of human diseases including (partially) caused by

ISSN 1996-4536 (print) • ISSN 2311-0783 (on-line) • Біологічні Студії / Studia Biologica • 2019 • Том 13/№1 • С. 71-84 
immune-metabolic disorders of the body. Modern studies of human microbiota and its functional properties (so-called function) open up today the possibilities for constructing a new generation of FFPs [24]. In this regard the most promising is a creation of FFP capable of direct and regulate intestinal microbiota of the individual, in particular for the prevention of obesity, type 2 diabetes, cardiovascular diseases and other noncommunicable diseases (NCDs) [6].

The aim of our study was to select in vitro and in vivo probiotic microorganisms, components of berries with predetermined properties. We developed on their basis a functional new generation food for prevention of NCD associated with the disturbed exchange of substances with probative use for regulating the intestinal microbiota. Besides, we developed the technological scheme of its production and study its properties.

\section{MATERIALS AND METHODS}

The basis for a compositional functional fermented drink was a pasteurized cow milk leavened by (L. casei ATCC 27139, L. plantarum JCM 1149, L. casei MGB63-1, L. plantarum in an amount not less than $10^{7} \mathrm{CFU} / \mathrm{ml}$ each strain). Previously, their high and selective antagonistic activity with respect to a number of opportunistic bacteria (namely, Klebsiella pneumoniae, Pseudomonas aeruginosa, Escherichia coli enteropathogenic (EPEC), Enterobacter cloacae, Morganella morganii, Staphylococcus aureus, methicillin-resistant S. aureus (MRSA), Staphylococcus hominis, Proteus mirabilis, Salmonella enterica subsp. enterica serovar Enteritidis, Shigella flexneri) has been demonstrated [3]. It was determined by the method of delayed antagonism and agar blocks behind Yegorov [3]. In addition, these strains of lactobacilli are characterized by specific immunomodulatory properties studied earlier in experiments on mice of the BALB / C line [3] and synergistic properties [6]. In similar studies, we have shown the ability of probiotic microorganisms to stimulate the local immune response and mechanisms that provide it $[15,19]$.

To make a sour-milk drink, we chose the native homogenates of the above-mentioned edible plants - dill (Anethum graveolens) and pomegranate (Púnica granátum), blueberries (Vaccinium murtillus L.) and cherry plum (Prunus divaricata) obtained using the Grindomix ${ }^{\mathrm{TM}}$ electric mixerin provided sterile conditions by using nylon nano-filters with a pore width of $44 \mu \mathrm{m}$ (BD Falcon, USA).

We used the dairy product prepared in the laboratory conditions. The manufacture of this drink was carried out under sterile conditions using classical technologies, according to the technological scheme (Fig. 1). Physico-chemical, organoleptic and sanitary-hygienic indices were determined according to DSTU 2661: 2010. The process of fermentation was controlled for acidity $75-90^{\circ} \mathrm{T}$.

Testing of the pro- and antimicrobial activity of end functional product was carried out by in vitro compatible culture experiment by placing $10 \mathrm{ml}$ of suspension of test strains of microorganisms (24-hour cultures) in a concentration of 0.5 according to McFarland $\left(1.5 \times 10^{8} \mathrm{CFU} / \mathrm{ml}\right)$ in test tubes. After 24,48 and 72 hours. Their co-incubation was determined by the number of microorganisms by sowing $10 \mu \mathrm{l}$ in a triple repetition on an appropriate nutrient medium.

The tested microorganisms belonged to different phylogenetic groups, and their etiological role was also distinct. These strains included: 1) museum strain test cultures (collectable strains) E. coli ATCC 25922 (F-50), S. aureus ATCC 25923 (F-49), P. aeruginosa ATCC 27853 (F-51)); 2) clinical isolates - pathogens of opportunistic infections (P. mirabilis, S. aureus and MRSA, E. cloacae, K. pneumoniae, P. aeruginosa), food

ISSN 1996-4536 (print) • ISSN 2311-0783 (on-line) • Біологічні Студії / Studia Biologica • 2019 • Том 13/№1 • С. 71-84 
poisonings (Salmonella enterica, S. flexneri, Listeria monocytogenes, EPEC) and 3) representatives of useful microbiota - commensal mucous membranes of the mouth (Lactobacillus salivarius) and intestines (E. coli 058, Enterococcus faecalis, Enterococcus faecium and Lactobacillus acidophilus); 4) probiotic microorganisms Lactobacillus fermentum, Bacillus subtilis 8130 and Saccharomyces cerevisiae.

For mathematical analysis of data, IBM SPSS Statistics V. 22.0 software was used; graphic processing of the data was done using Origin 10.

\section{RESULTS AND DISCUSSION}

Nutrition is undoubtedly a major modifiable determinant of a disease. At the recent United Nations general assembly on the NCD prevention and control, the importance of establishing preventative health strategies was widely acknowledged [17]. One of the main factors was proposed changes in food choices and the increased use of functional foods to prevent of $\operatorname{NCD}[17,23,25]$. Modulating the intestinal microbiota via dietary interventions is becoming a promising strategy for verifying a cause of chronic inflammation involved in obesity and metabolic syndrome [25].

When creating a new generation FFPs one of the main steps is to select and justify a choice of ingredients that should provide new expected properties of the composite product.

Based on the results of our previous studies [3, 15], we have proposed the principles of creating a new generation FFP based on plant components and microorganisms for the purpose of their prognostic and personified application for preventing the emergence of noncommunicable diseases [6], through correction of microbial cenosis in the intestines of the macroorganism .

We produced a functional sour milk drink based on the lactobacilli with the desired functional properties - the ability to provide antimicrobial action of opportunistic microorganisms and to modulate the intestinal microbiota. Other scientists proved in vivo that if an insufficient number of lactobacilli observed a significant decrease in the number of bifidobacteria [3].

The isolated Lactobacillus strains are characterized by selective antagonistic activity in relation to conditionally pathogenic bacteria, namely: K. pneumoniae, $P$. aeruginosa, E. coli, E. cloacae, M. morganii, S. aureus, methicillin-resistant S. aureus (MRSA), S. hominis, P. mirabilis, S. enteritidis, S. flexneri [3] established in vitro.

Our task was to choose natural plant fillers rich in BAS to enhance the qualities of the functional product, that would have the ability to synergize and provide the desired effect on the intestinal microbe. For this purpose, we have selected previously extracted edible extracts of various edible plants with known effects on different groups of microorganisms [13, 30].

Our studies have shown that selected extracts not only inhibited the main representatives - test and clinical strains, pathogenic and opportunistic bacteria, but were capable of stimulating useful commensal microorganisms of the intestine. Such actions were characterized by the extracts of blueberries ( $V$. murtillus L.), aliche ( $P$. divaricata), pomegranate $(P$. granátum), dill ( $A$. graveolens) [13]. Prebiotic plant components rich in BAS are able to regulate a balance of microbiota in the gastrointestinal tract - shown in experiments in vivo, previously investigated and characterized by an expressive antioxidant and anti-inflammatory properties $[13,30]$. Thus, created by their combination in the form of a new functional beverage can potentially prevent the emergence of both

ISSN 1996-4536 (print) • ISSN 2311-0783 (on-line) • Біологічні Студії / Studia Biologica • 2019 • Том 13/№1 • C. 71-84 
infectious and human NCD, caused by respectively pathogenic and opportunistic microorganisms or microbial disorders and associated chronic inflammation [3, 12].

A brief technological process is described here: pasteurized milk ( $\mathrm{T}=80{ }^{\circ} \mathrm{C}, 10$ $15 \mathrm{~min}$ ) was cooled to $\mathrm{T}=40 \pm 2{ }^{\circ} \mathrm{C}$, introduced with the strains of microorganisms and mixed. The function of the starter cultures is to ferment lactose (milk sugar) to produce lactic acid. An increase in lactic acid decreases $\mathrm{pH}$ and causes the milk to clot, or form a soft gel that is characteristic of sour milk drink [5]. By using a thermostat method, milk is held at $40 \pm 2{ }^{\circ} \mathrm{C}$ until a $\mathrm{pH} 4.7$ is reached. This allows the fermentation to form a soft gel and the characteristic flavor of sour milk drink. This process can take 6-8 hours after which the half of product was cooled and stored at $3-5^{\circ} \mathrm{C}$ for $3-7$ days. In order to prevent the destruction of BAS just before the use in the end intermediate product, homogenates of blueberries / cherry plum / pomegranate or fresh dill were added in the ratio of 5-7 percent. A technological scheme of making a sour-milk drink is shown in Fig.1.

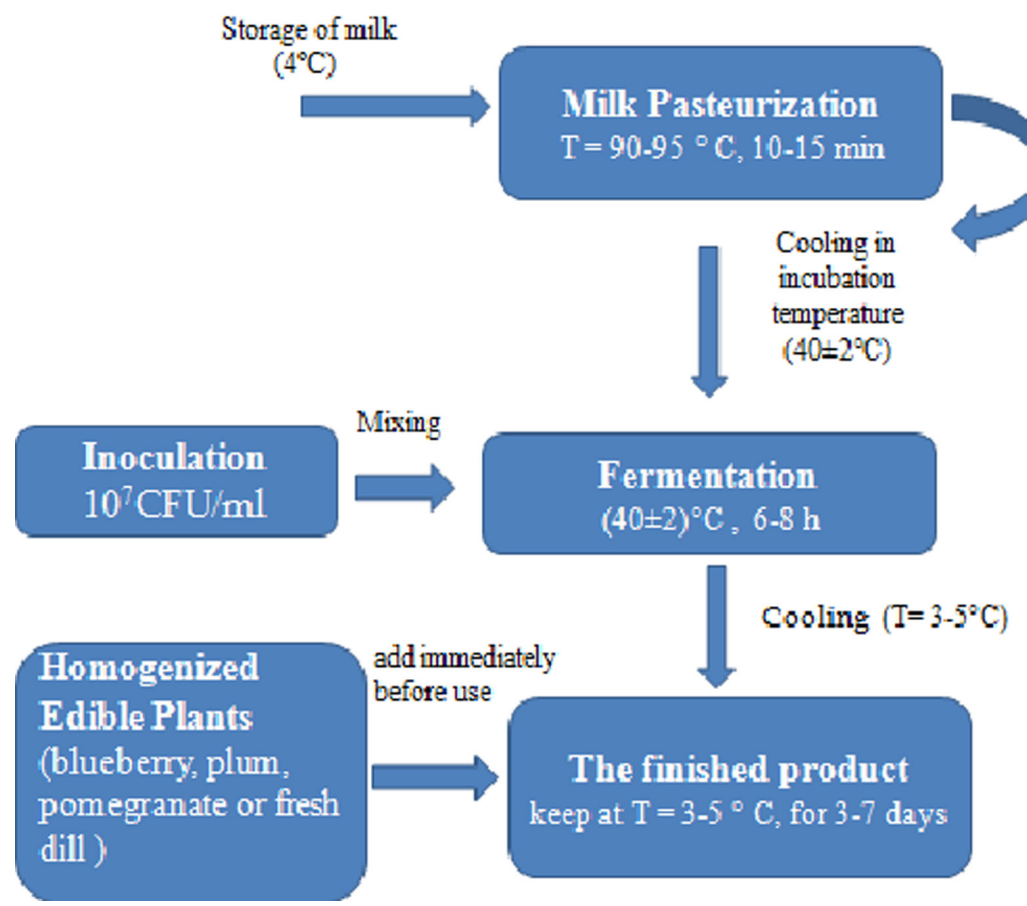

Fig. 1. Flowchart preparation of a sour-milk drink with various edible plant extracts

Рис. 1. Технологічна схема приготування кисломолочного напою з різними їстівними рослинними екстрактами

Throughout a period of storage of the half-finished product, the number of authored microorganisms were determined by seeding serial dilutions of the FFP on the medium with added marker antibiotics for indicating each of strains of lactobacilli. During the first 7 days, high titres of lactobacilli above $10^{8} \mathrm{CFU} / \mathrm{ml}$ (according to DSTU 2661: 2010, not less than $10^{7} \mathrm{CFU} / \mathrm{ml}$ ), on the 8th day of storage, the number of all lactobacilli decreased significantly that substantiates the suitability of the product within 3-7 days (Fig. 2).

ISSN 1996-4536 (print) • ISSN 2311-0783 (on-line) • Біологічні Студії / Studia Biologica • 2019 • Том 13/№1 • С. 71-84 


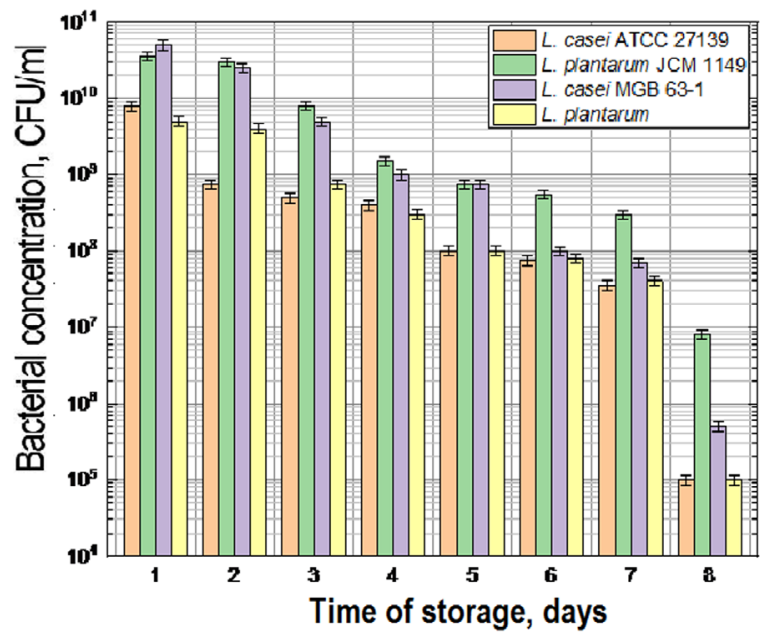

Fig. 2. Changes in a number of strains of lactobacilli in the sour-milk drink (semifind product), during 8 days of storage

Рис. 2. Зміни кількості авторських штамів лактобактерій у кисломолочному напої (напівпродукті) протягом 8 днів зберігання

Table 1. Results of coherent cultivation of tested microorganisms with the developed sour-milk semifind product

Таблиця 1. Результати сумісного культивування тестованих мікроорганізмів з розробленим нами кисломолочним напівпродуктом

Tested microorganisms

E. coli ATCC 25922

E. coli EPEC

E. coli (Shaedler's strain)

E. coli 058

S. enteritidis

S. dysenteriae

E. cloacae

M. morganii

P. mirabilis

P. aeruginosa

S. aureus

MRSA

K. pneumoniae

E. faecalis

L. acidophilus

L. salivarius

S. cerevisiae

B. subtilis 8130

Co-cultivation, hours and number of cultured microorganisms, CFU/ml

24

$(7.3 \pm 0.3) \cdot 10^{9}$

$(4 \pm 0.2) \cdot 10^{8}$

$(1.1 \pm 0.1) \cdot 10^{9}$

$(7 \pm 0.4) \cdot 10^{8}$

$(1.8 \pm 0.2) \cdot 10^{4}$

$(2 \pm 0.1) \cdot 10^{6}$

$(6.8 \pm 0.3) \cdot 10^{6}$

$(7.5 \pm 0.5) \cdot 10^{7}$

$>10^{8}$

$>10^{8}$

$10^{8}$

$10^{8}$

$(6 \pm 0.2) \cdot 10^{10}$

$(1.5 \pm 0.1) \cdot 10^{7}$

$(3.8 \pm 0.3) \cdot 10^{9}$

$(5 \pm 0.1) \cdot 10^{9}$

$(4 \pm 0.3) \cdot 10^{9}$
48

$(8 \pm 0.4) \cdot 10^{6}$
0

$(3.4 \pm 0.4) \cdot 10^{3}$

$(1.5 \pm 0.1) \cdot 10^{3}$

0

0

$10^{6}$

$(4 \pm 0.3) \cdot 10^{4}$

$>10^{8}$

$10^{8}$

$(6.6 \pm 0.3) \cdot 10^{3}$

$(5 \pm 0.1) \cdot 10^{4}$

$(3.5 \pm 0.1) \cdot 10^{8}$

$(4 \pm 0.3) \cdot 10^{4}$

$10^{8}$

$(8 \pm 0.4) \cdot 10^{8}$

$>10^{8}$

$(8 \pm 0.4) \cdot 10^{8}$

\section{2}

$(2.5 \pm 0.2) \cdot 10^{5}$

0

$(2.5 \pm 0.3) \cdot 10^{2}$

$(2.0 \pm 0.1) \cdot 10^{2}$

0

0

$(5.6 \pm 0.3) \cdot 10^{9}$

$(1 \pm 0.1) \cdot 10^{4}$

$(3.1 \pm 0.2) \cdot 10^{9}$

$(7.9 \pm 0.5) \cdot 10^{9}$

$(2 \pm 0.1) \cdot 10^{3}$

$(1.5 \pm 0.1) \cdot 10^{4}$

$(2.5 \pm 0.1) \cdot 10^{7}$

$(1.8 \pm 0.1) \cdot 10^{3}$

$10^{9}$

$(2 \pm 0.2) \cdot 10^{8}$

$>10^{8}$

$>10^{8}$

ISSN 1996-4536 (print) • ISSN 2311-0783 (on-line) • Біологічні Студії / Studia Biologica • 2019 • Том 13/№1 • С. 71-84 
The proposed sour-milk product with authorss strains and various edible plant extracts were characterized by a selective antimicrobial ability in addition to the anti-inflammatory effect that was proven earlier.

Data listed in Table 1 indicate the ability of this semi-finished product (without plant extracts) after 48 hours of compatible cultivation to delay the growth of the opportunistic and pathogenic strains of microorganisms: EPEC, Salmonella enterica and Shigella dysenteriae. For 72 hours of co-cultivation, it was found at least a smaller but still significant inhibitory effect of this semifinished product on the comensal Escherichia stains - E. coli 058 and $E$. coli (Shaedler's strain) was less significant, the micro-organism titers were sown in amount $(2.0 \pm 0.1) \times 10^{2} \mathrm{CFU} / \mathrm{ml}$ and $(2.5 \pm 0.3) \times 10^{2} \mathrm{CFU} / \mathrm{ml}$. A decrease in concentration of E. coli strains ATCC 25922 and E. faecalis was observed at a later date and to a lesser extent.

At the same time, we established the pro-bacterial property of this semi-product with a respect to the representatives of commensal microbiota, such as $L$. acidophilus, $L$. salivarius, as well as probiotic microorganisms B. subtilis 8130 and S. cerevisiae cultured throughout the study in a large number $\left(10^{8}-10^{9}\right) \mathrm{CFU} / \mathrm{ml}$. However, this intermediate product did not exhibit bactericidal action against $P$. mirabilis, $P$. aeruginosa, E. cloacae, in contrast to the author strains characterized by such action.

Examples of the antagonistic activity of the developed half-product are also shown in Fig. 3
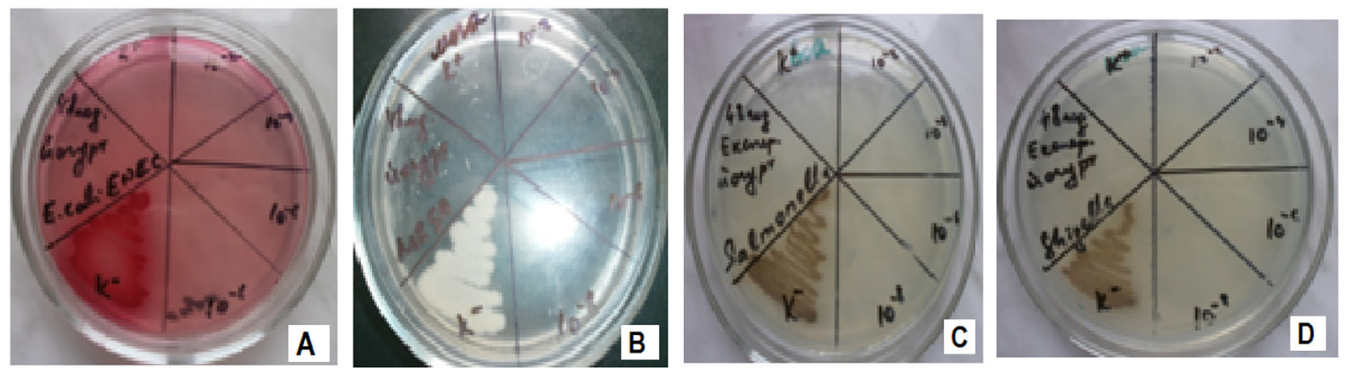

Fig. 3. The antagonistic property of the half-product developed by the method of compatible cultivation in relation to the strains we tested for opportunistic microorganisms - quantitative assessment: $A-$ E. coli EPEC; $B$ - MRSA; $C$ - Salmonella enterica subsp. enterica serovar Enteritidis; $D$ - S. dysenteriae

Note: for qualitative culturing, three test tubes were prepared: positive control $\left(\mathrm{K}^{+}\right)$: semi-finished + bacterial suspension (in the amount of 1: 1); Experiment $(E)$ : semi-finished + bacterial suspension + MPA (MRS broth) (in a quantity of 1: 1: 1); Negative control (K-): suspension of the microorganism + MPA (MRS broth) (in the number 1: 1). The contents of each test tube were sown on the appropriate portions of Petri's dish ( $\left.\mathrm{K}^{+}, \mathrm{E}, \mathrm{K}^{-}\right)$. Quantitative method - culturing by sectors

Рис. 3. Антагоністична властивість розробленого нами напівпродукту методом сумісного культивування стосовно тестованих нами штамів умовно-патогенних мікроорганізмів - кількісна оцінка: $A-$ E. coli EPEC; B - MRSA; C - Salmonella enterica підвид enterica серовар Enteritidis; $D$ S. dysenteriae

Примітка: для якісного висіву готували три пробірки: позитивний контроль $\left(\mathrm{K}^{+}\right)$: напівпродукт + бактеріальна суспензія (в кількості 1:1); Експеримент (Е): напівпродукт + бактеріальна суспензія + МПБ (MRS бульйон) (в кількості 1:1:1); негативний контроль (К): суспензія мікроорганізму + МПБ (MRS бульйон) (в кількості 1:1). Вміст кожної пробірки висівали на відповідні сектори

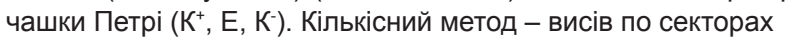

ISSN 1996-4536 (print) • ISSN 2311-0783 (on-line) • Біологічні Студії / Studia Biologica • 2019 • Том 13/№1 • С. 71-84 
The same method of co-cultivation determined the spectrum of anti- and pro-microbial properties of the final functional product already with the blueberry extracted (homogenate) added (Table 2). The end product, similar to the previous half-product, had an ability to inhibit the pathogens of intestinal infections of EPEC, Salmonella enterica subsp. enterica serovar Enteritidis, S. dysenteriae until a complete inhibition of their growth after 72 hours of co-cultivation. Also, the essential antibacterial activity of the sour milk beverage with blueberry extract was established in relation to a number of the opportunistic microorganisms such as M. morganii, S. aureus, MRSA, E. coli. The same effect was observed for E. coli ATCC 25922 collection strain.

Table 2. Results of co-cultivation of tested microorganisms and sour-milk drink with blueberries

Таблиця 2. Результати сумісного культивування тестованих мікроорганізмів і кисломолочного напою $з$ чорницею

\begin{tabular}{|c|c|c|c|}
\hline \multirow[t]{2}{*}{ Tested microorganisms } & \multicolumn{3}{|c|}{$\begin{array}{l}\text { Co-cultivation, hours and number of isolated microorganisms, } \\
\text { CFU/ml }\end{array}$} \\
\hline & 24 hours & 48 hours & 72 hours \\
\hline E. coli ATCC 25922 & $(1.6 \pm 0.1) \cdot 10^{8}$ & $(2 \pm 0.2) \cdot 10^{5}$ & 0 \\
\hline EPEC & $(1.8 \pm 0.2) \cdot 10^{8}$ & $(4 \pm 0.1) \cdot 10^{6}$ & 0 \\
\hline E. coli Shaedler's strain & $(1.9 \pm 0.1) \cdot 10^{8}$ & $(2 \pm 0.1) \cdot 10^{3}$ & $(1.8 \pm 0.1) \cdot 10^{2}$ \\
\hline E. coli 058 & $(1.6 \pm 0.3) \cdot 10^{8}$ & $(8 \pm 0.3) \cdot 10^{4}$ & $(3.2 \pm 0.2) \cdot 10^{3}$ \\
\hline S. enteritidis & 0 & 0 & 0 \\
\hline S. dysenteriae & 0 & 0 & 0 \\
\hline E. cloacae & $(1.6 \pm 0.1) \cdot 10^{7}$ & $(2 \pm 0.2) \cdot 10^{5}$ & $(3.4 \pm 0.3) \cdot 10^{3}$ \\
\hline M. morganii & $(5 \pm 0.3) \cdot 10^{6}$ & $(8.5 \pm 0.5) \cdot 10^{3}$ & 0 \\
\hline P. mirabilis & $>10^{8}$ & $(1.3 \pm 0.3) \cdot 10^{7}$ & $(1.5 \pm 0.1) \cdot 10^{3}$ \\
\hline$P$. aeruginosa & $(1.7 \pm 0.2) \cdot 10^{7}$ & $(2.7 \pm 0.3) \cdot 10^{7}$ & $(1.8 \pm 0.2) \cdot 10^{7}$ \\
\hline S. aureus & $(1.6 \pm 0.1) \cdot 10^{5}$ & $(5.5 \pm 0.1) \cdot 10^{3}$ & 0 \\
\hline MRSA & $(3 \pm 0.3) \cdot 10^{8}$ & $10^{4}$ & 0 \\
\hline K. pneumoniae & $(3.5 \pm 0.2) \cdot 10^{8}$ & $(1.5 \pm 0.1) \cdot 10^{6}$ & $10^{4}$ \\
\hline E. faecalis & $(1.5 \pm 0.1) \cdot 10^{8}$ & $(2.6 \pm 0.3) \cdot 10^{3}$ & $(2.0 \pm 0.3) \cdot 10^{3}$ \\
\hline L. fermentum & $(5.9 \pm 0.4) \cdot 10^{9}$ & $>10^{8}$ & $(2 \pm 0.1) \cdot 10^{9}$ \\
\hline L. acidophilus & $(6 \pm 0.2) \cdot 10^{8}$ & $(1.5 \pm 0.1) \cdot 10^{9}$ & $(2 \pm 0.1) \cdot 10^{8}$ \\
\hline S. cerevisiae & $(1.8 \pm 0.1) \cdot 10^{8}$ & $>10^{8}$ & $>10^{8}$ \\
\hline B. subtilis 8130 & $>10^{8}$ & $10^{6}$ & $>10^{8}$ \\
\hline
\end{tabular}

At the same time, a new generation of FFP stimulated a growth of representatives of useful microbiota. So the amount of lactobacilli isolated from the mucous membranes of the mouth and intestines of healthy individuals were stable for 72 hours of compatible cultivation - up to $10^{8}-10^{9} \mathrm{CFU} / \mathrm{ml}$, and the content of the probiotic L. fermentum strain was also high.

The content of representatives of E. coli, E. faecalis, E. coli Schaedler's strain, $E$. coli 058 also decreased somewhat, and the strains did not exceed the amount of $10^{2}-10^{3} \mathrm{CFU} / \mathrm{ml}$ on the third day of testing.

Despite the previously established ability of blueberries extract to completely suppress the growth of clinical strains $P$. mirabilis and $P$. aeruginosa, the end product was not characterized by such properties.

ISSN 1996-4536 (print) • ISSN 2311-0783 (on-line) • Біологічні Студії / Studia Biologica • 2019 • Том 13/№1 • C. 71-84 
Figure 4 presents examples of the antagonistic activity of a end sour-milk drink with a native extract of blueberries using a co-cultivating method in relation to EPEC and E. coli ATCC 25922; M. morganii; Salmonella enterica subsp. enterica serovar Enteritidis.

The results of the combined culturing effects of the tested microorganisms in the developed fermented milk product with cherry plum are shown in Table 3.

The antibacterial activity in vitro of the sour-milk product with pomegranate for a prevention and treatment of food-borne toxic infections and non-infectious human pathologies caused by the excited metabolism of the following strains of microorganisms: E. coli ATCC 25922, EPEC, S. enteritidis, S. dysenteriae was also established in in vitro studies. Probacterial activity of sour-milk drink in relation to representatives of useful microbiota of functional product with a pomegranate in relation to strains $L$. fermentum and $L$. acidophilus. The antibacterial activity of the new product in relation to $S$. enteritidis, $S$. dysenteriae, $S$. aureus has been established. The dairy drink with cherry plum showed antibacterial activity against strains of microorganisms: E. coli ATCC 25922, EPEC, S. aureus, MRSA, S. enteritidis, S. dysenteriae, $P$. aeruginosa, E. cloacae. The dairy product with blueberries was suppressed by: P. aeruginosa, M. morganii, L. monocytogenes, S. enteritidis, S. dysenteriae, S. aureus, E. coli ATCC 25922, EPEC, MRSA, and also comensal strains of E. coli 058 and E. coli Schaedler's.

For the third day of testing a number of $K$. pneumoniae also decreased, and did not exceed the amount of $10^{7}-10^{4} \mathrm{CFU} / \mathrm{ml}$. However, it has been noted that suppressive action has increased with the addition of native extracts (blueberries / cherry plum / dill / pomegranate). Cherry plum and pomegranate had a greater antagonistic effect on K. pneumoniae and Klebsiella oxytoca.
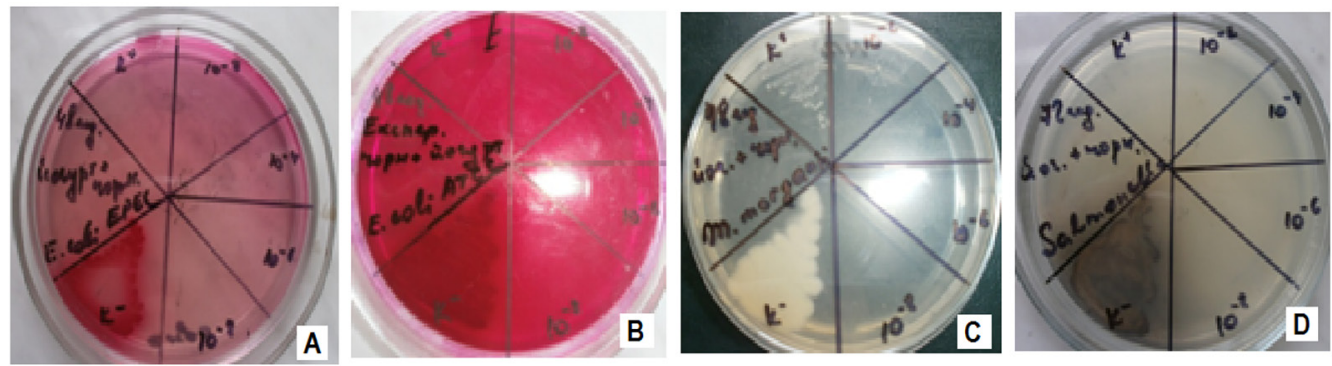

Fig. 4. Determination of the antagonistic activity of the end sour-milk drink with a native extract of blueberries by the method of compatible cultivation in relation to some tested strains of microorganisms: $A-$ EPEC; $B-$ E. coli ATCC 25922; C - M. morganii; D - Salmonella enterica subsp. enterica serovar Enteritidis

Note: for qualitative culturing, three test tubes were prepared: positive control $\left(\mathrm{K}^{+}\right)$: product + bacterial suspension (in a quantity of 1: 1); Experiment (E): product + bacterial suspension + MPA (MRS broth) (in the amount of 1: 1: 1); Negative control $\left(\mathrm{K}^{-}\right)$: suspension of the microorganism + MPA (MRS broth) (in the number 1: 1). The contents of each test tube were sown on the appropriate portions of Petri's cup $\left(\mathrm{K}^{+}, \mathrm{E}, \mathrm{K}^{-}\right)$. Quantitative method - culture by sectors

Рис. 4. Визначення антагоністичної активності готового кисломолочного напою з нативним екстрактом чорниці методом сумісного культивування стосовно деяких тестованих штамів мікроорганізмів: A - EPEC; B - E. coli ATCC 25922; C - M. morganii; D - Salmonella enterica підвид еnterica серовар Enteritidis

Примітка: для якісного висіву готували три пробірки: позитивний контроль $\left(\mathrm{K}^{+}\right)$: продукт + бактеріальна суспензія (в кількості 1:1); Експеримент (Е): продукт + бактеріальна суспензія + МПБ (MRS бульйон) (в кількості 1:1:1); негативний контроль (К): суспензія мікроорганізму + МПБ (MRS бульйон) (в кількості 1:1). Вміст кожної пробірки висівали на відповідні сектори чашки

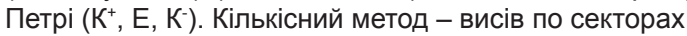

ISSN 1996-4536 (print) • ISSN 2311-0783 (on-line) • Біологічні Студії / Studia Biologica • 2019 • Том 13/№1 • С. 71-84 
Table 3. Results of coherent cultivation of tested microorganisms and a new dairy product with cherry plum

Таблиця 3. Результати сумісного культивування тестованих мікроорганізмів і нового кисломолочного продукту з аличею

\begin{tabular}{lcccc}
\hline \multicolumn{1}{c}{ Test microorganisms } & \multicolumn{3}{c}{ Co-culture, hour and number of isolated microorganisms, } \\
\hline & 24 & CFU/ml & 72 \\
\hline E. coli 058 & $10^{8}$ & $(0,5 \pm 0,1) \cdot 10^{4}$ & $10^{3}$ \\
\hline E.coli Schaedler's strain & $(1.5 \pm 0.1) \cdot 10^{10}$ & $10^{4}$ & $10^{2}$ \\
\hline E. coli ATCC 25922 & $(3 \pm 0.1) \cdot 10^{6}$ & $(7.5 \pm 0.3) \cdot 10^{2}$ & 0 \\
\hline EPEC & $(1.5 \pm 0.1) \cdot 10^{5}$ & 0 & 0 \\
\hline E. faecalis & $(2 \pm 0.2) \cdot 10^{6}$ & $(2 \pm 0.2) \cdot 10^{5}$ & $(1.5 \pm 0.1) \cdot 10^{4}$ \\
\hline P. mirabilis & $(2.5 \pm 0.2) \cdot 10^{10}$ & $10^{10}$ & $(2 \pm 0.2) \cdot 10^{10}$ \\
\hline P. aeruginosa & $(2.5 \pm 0.1) \cdot 10^{8}$ & $(4 \pm 0.1) \cdot 10^{6}$ & $(3 \pm 0.1) \cdot 10^{2}$ \\
\hline L. monocytogenes & $10^{10}$ & $(8 \pm 0.4) \cdot 10^{6}$ & $(1.5 \pm 0.1) \cdot 10^{6}$ \\
\hline M. morganii & $(7 \pm 0.4) \cdot 10^{8}$ & $10^{10}$ & $(4.5 \pm 0.2) \cdot 10^{10}$ \\
\hline E. cloacae & $(8 \pm 0.3) \cdot 10^{8}$ & $(1.5 \pm 0.1) \cdot 10^{5}$ & $(6.5 \pm 0.4) \cdot 10^{2}$ \\
\hline S. aureus & $(2 \pm 0.2) \cdot 10^{7}$ & $(3.5 \pm 0.3) \cdot 10^{4}$ & 0 \\
\hline MRSA & $(9.5 \pm 0.1) \cdot 10^{6}$ & $(1.5 \pm 0.1) \cdot 10^{4}$ & 0 \\
\hline K. pneumoniae & $(8 \pm 0.4) \cdot 10^{8}$ & $(0.5 \pm 0.1) \cdot 10^{7}$ & $(0.5 \pm 0.1) \cdot 10^{5}$ \\
\hline S. enteritidis & $(2 \pm 0.1) \cdot 10^{4}$ & 0 & 0 \\
\hline S. dysenteriae & $(3 \pm 0.1) \cdot 10^{3}$ & 0 & 0 \\
\hline L. fermentum & $(2.5 \pm 0.2) \cdot 10^{10}$ & $(2 \pm 0.1) \cdot 10^{10}$ & $>10^{10}$ \\
\hline L. salivarius & $10^{8}$ & $(2 \pm 0.2) \cdot 10^{10}$ & $(5 \pm 0.3) \cdot 10^{10}$ \\
\hline L. acidophilus & $(9 \pm 0.4) \cdot 10^{10}$ & $(5 \pm 0.2) \cdot 10^{8}$ & $(2 \pm 0.1) \cdot 10^{10}$
\end{tabular}

The obtained data are relevant because it proves a possibility of creating (constructing) a new generation of FFP with predetermined properties, namely those that are capable of selectively adjusting the balance of microbiota of the gastrointestinal tract and preventing the emergence of infectious or associated with inadequate nutrition of somatic pathologies.

We used new approaches for production of FFP. They are characterized primarily by the patient-oriented (personified) purpose, as they allow adjusting their composition based on individual indices of intestinal microbial patients or healthy individuals. It is the basis of targeted diet and prevention of diet and diagnosis of human diseases by supporting and / or correction pro- or anti-inflammatory processes of mucous membranes of the body [6] associated with the colonization of mucous membranes by the microorganism.

\section{CONCLUSIONS}

We proposed new principles and approaches in a design of new generation of FFPs developed on the basis of pre-selected plant components and microorganisms for the purpose of their prognostic and personalized use to prevent the emergence of NCD through targeted correction of microbial cenosis in the gut of the macroorganism and effective also in the treatment of a certain number food poisoning.

ISSN 1996-4536 (print) • ISSN 2311-0783 (on-line) • Біологічні Студії / Studia Biologica • 2019 • Том 13/№1 • С. 71-84 
The antibacterial activity in vitro of the sour-milk product for the prevention and treatment of food-borne toxic infections and non-infectious human pathologies caused by the excited metabolism of the following strains of microorganisms: E. coli ATCC 25922, EPEC, Salmonella enterica subsp. enterica serovar Enteritidis (S. Enteritidis), S. dysenteriae was also established in in vitro studies. The dairy drink with cherry plum showed antibacterial activity against strains of microorganisms: E. coli ATCC 25922, EPEC, S. aureus, MRSA, S. Enteritidis, S. dysenteriae, P. aeruginosa, E. cloacae; The dairy product with blueberries was suppressed by: P. aeruginosa, M. morganii, L. monocytogenes, S. Enteritidis, S. dysenteriae, S. aureus, E. coli ATCC 25922, EPEC, MRSA, and also comensal strains of E. coli 058 and E. coli Schaedler's strain. It was noted that a suppressive action has increased with the addition of native extracts (blueberries / cherry plum / dill / pomegranate). Cherry plum and pomegranate had a greater antagonistic effect on K. pneumoniae and Klebsiella oxytoca.

A probacterial activity of sour-milk drink in relation to representatives of useful microbiota of functional product with a pomegranate/ blueberries / cherry plum / dill in relation to strains $L$. fermentum and $L$. acidophilus.

A new sour-milk product of variable composition of components with synergistic action provides a simultaneous normalization of intestinal microbiota and suppresses growth of opportunistic and pathogenic microorganisms. The added value of such product is the presence of BAS of edible plants and berries of local origin characterized by a proven anti-inflammatory action.

\section{ACKNOWLEDGMENTS}

This work is funded under the EU FP7 Theme 2: "Food, agriculture, fisheries, and biotechnology", Project BaSeFood ; Grant Agreement no: 227118. [http://www.basefood-fp7.eu/www.basefood-fp7.eu/index.html'] and State governmental budget of Ministry of Education and Science, Topic: "Implementation of new approaches to the creation and applying of modern pharmabiotics" Registration number 0117 U000379.

1. Arena M.P., Russo P., Capozzi V., López P., Fiocco D., Spano G. Probiotic abilities of riboflavin-overproducing Lactobacillus strains: a novel promising application of probiotics. Applied Microbial and Cell Physiology Journal, 2014; 98(17): 7569-7581.

[DOI: 10.1007/s00253-014-5837-x; Google Scholar]

2. Ballal S.A., Veiga P., Fenn K. et al. Host lysozyme-mediated lysis of Lactococcus lactis facilitates delivery of colitis-attenuating superoxide dismutase to inflamed colons. Proceedings of the National Academy of Sciences of the United States of America, 2015; 112(25); 7803-7808.

[DOI: https://doi.org/10.1073/pnas.1501897112; Google Scholar]

3. Bati V., Boyko N. The biological properties of Lactobacilli, isolated from ethnical foods and edible plants. J."ScienceRise: Biological Science", 2016; 25(8/1): 6-14. (In Ukrainian) [DOI: https://doi.org/10.15587/2313-8416.2016.76712; Google Scholar]

4. Bati V., Boyko N. The microbial diversity and its dynamics in the ethnic fermented foods of the Black sea region. Microb J., 2016; 78(5): 53-64.

[PMID:30141865; Google Scholar]

5. Batista A.L.D., Silva R., Cappato L.P. et al. Developing a synbiotic fermented milk using probiotic bacteria and organic green banana flour. Journal of functional foods, 2017; 38: 242-250. [DOI: https://doi.org/10.1016/j.jff.2017.09.037; Google Scholar]

6. Bubnov, R.V., Spivak, M.Ya., Lazarenko, L.M., Bomba A., Boyko N.V. Probiotics and immunity: provisional role for personalized diets and disease prevention. EPMA Journal, 2015; 6: 14. [DOI: 10.1186/s13167-015-0036-0; PMID:26221192; PMCID:pmc4517425; Google Scholar]

ISSN 1996-4536 (print) • ISSN 2311-0783 (on-line) • Біологічні Студії / Studia Biologica • 2019 • Том 13/№1 • С. 71-84 
7. Deriu E., Liu J.Z., Pezeshki M. et al. Probiotic bacteria reduce Salmonella typhimurium intestinal colonization by competing for iron. Cell Host Microbe Journal, 2013; 14(1): 26-37. [DOI:https://doi.org/10.1016/j.chom.2013.06.007; Google Scholar]

8. Derrien M., Veiga P. Rethinking Diet to Aid Human-Microbe Symbiosis. Trends Microbiol., 2017; 25(2): 100-112.

[DOI: https://doi.org/10.1016/j.tim.2016.09.011; PMID: 27916707; Google Scholar]

9. Durzhinska O.A. Healthy eating is one of the most important health factors. Agricultural Science and Food Technology, 2017; 5(2): 139-147. (In Ukrainian)

10. Ercolini D., Fogliano V. Food Design To Feed the Human Gut Microbiota. Journal of Agricultural and Food Chemistry, 2018; 66(15): 3754-3758.

[DOI: 10.1021/acs.jafc.8b00456; PMCID: PMC5951603; PMID: 29565591; Google Scholar]

11. Grebenyuk M. Regulation of food security in the legislation of the European Union and Ukraine. // K.: Publishing House of the Ministry of Justice of Ukraine. 2012: 301. (In Ukrainian)

12. Kobyliak N., Falalyeyeva T., Boyko N., Tsyryuk O., Beregova T., Ostapchenko L. Probiotics and nutraceuticals as a new frontier in obesity prevention and management. Diabetes Research and Clinical Practice, 2018; 141:190-199.

[DOI: https://doi.org/10.1016/j.diabres.2018.05.005; PMID:29772287; Google Scholar]

13. Konic-Ristic A., Srdic-Rajic T., Kardum N., Aleksić-Veličković V., Kroon P., Hollands W., Needs P., Boyko N., Hayran O., Jorjadze M., Glibetic M. Effects of bioactive-rich extracts of pomegranate, persimmon, nettle, dill, kale and Sideritis and isolated bioactives on arachidonic acid induced markers of platelet activation and aggregation. J. Sci Food Agric., 2013; 93(14): 3581-7.

[DOI: https://doi.org/10.1002/jsfa.6328; PMID:23900938; Google Scholar]

14. Kovalenko N.K. Dairy products, their quality and impact on human health. J. Problems of Nutrition., 2003;1: 78-81. (In Ukrainian)

15. Lazarenko L.M., Babenko L.P., Bubnov R.V., Demchenko O.M., Zotsenko V.M., Boyko N.V., Spivak M. Ya. Imunobiotics are the Novel Biotech drugs with antibacterial and immunomodulatory properties. Microb J., 2017; 79(1): 66-75. [Google Scholar]

16. Lyte Mark. Probiotics function mechanistically as delivery vehicles for neuroactive compounds: Microbial endocrinology in the design and use of probiotics. Bioessays, 2011; 33(8): 574-581.

[DOI: 10.1002/bies.201100024; PMID: 21732396; Google Scholar ]

17. Lenoir-Wijnkoop, P.J. Jones, R. Uauy, L. Segal, J. Milner. Nutrition economics - food as an ally of public health. British Journal of Nutrition, 2013; 109(5): 777-784.

[DOI: https://doi.org/10.1017/S0007114512005107; Google Scholar]

18. Mafra D., Borges N., Alvarenga L., Esgalhado M., Cardozo L., Lindholm B., Stenvinkel P. Dietary Components That May Influence the Disturbed Gut Microbiota in Chronic Kidney Disease. Nutrients Journal, 2019, 11(3), 496-519.

[DOI: https://doi.org/10.3390/nu11030496; PMID: 30818761; PMCID: PMC6471287; Google Scholar]

19. Mokrozub V.V., Lazarenko L.M., Sichel L.V., Babenko L.P., Lytvyn P.M., Demchenko O.M., Melnichenko Yu.M., Boyko N.V., Biavati B., DiGioia D., Bubnov R.V., Spivak M.Ya. The role of beneficial bacteria wall elasticity in regulating innate immune response. EPMA Journal, 2015; $6: 13$.

[DOI: https://doi.org/10.1186/s13167-015-0035-1; Google Scholar]

20. Molina V. C., Médici M., Taranto M. P., Font de Valdez G. Lactobacillus reuteri CRL 1098 prevents side effects produced by a nutritional vitamin $B_{12}$ deficiency. Journal of Applied Microbiology, 2009; 106(2): 467-473.

[DOI: https://doi.org/10.1111/j.1365-2672.2008.04014.x; Google Scholar]

21. Mullaney J.A., Kelly W.J., McGhie T.K., Ansell J., Heyes J.A. Lactic acid bacteria convert glucosinolates to nitriles efficiently yet differently from Enterobacteriaceae. Journal of Agricultural and Food Chemistry. 2013; 61(12): 3039-3046.

[DOI: 10.1021/jf305442j; Google Scholar]

ISSN 1996-4536 (print) • ISSN 2311-0783 (on-line) • Біологічні Студії / Studia Biologica • 2019 • Том 13/№1 • C. 71-84 
22. Nagpal R., Wang Sh., Ahmadi Sh. et al. Human-origin probiotic cocktail increases shortchain fatty acid production via modulation of mice and human gut microbiome. Scientific Reports Journal, 2018; 8: 1-15.

[DOI: 10.1038/s41598-018-30114-4; PMID:30139941 PMCID:pmc6107516; Google Scholar]

23. Nurul FarhanaFazilah, Arbakariya B. Ariff, Mohd EzuanKhayat, Leonardo Rios-Solis, Murni Halim. Influence of probiotics, prebiotics, synbiotics and bioactive phytochemicals on the formulation of functional yogurt. Journal of Functional Foods, 2018; 48: 387-399.

[DOI: https://doi.org/10.1016/j.jff.2018.07.039; Google Scholar]

24. Rettedal E.A., Altermann E., Roy N.C., Dalziel J.E. The Effects of Unfermented and Fermented Cow and Sheep Milk on the Gut Microbiota. Journal Frontiers in Microbiology, 2019; 10: 458.

[DOI:10.3389/fmicb.2019.00458; PMID: 30930871; PMCID: PMC6423907]

25. Rosângela dos Santos Ferreira, Rita de Cássia Avellaneda Guimarães, Ligia Aurélio Bezerra Maranhão Mendonça, Priscila Aiko Hiane. The Impact of Functional Food on the Intestinal Microbiota in Relation to Chronic Noncommunicable Diseases. Journal of Annals of Pancreatic Disorders and Treatment, 2017; 1(1): 004-006.

[DOI: http://dx.doi.org/10.17352/apdt.000002]

26. Shemeta O., Dozhuk K. Functional Foods - a New Approach to a Healthy Lifestyle. J. „Ukrainian Medicines", 2015; 1(186): 24-27. (In Ukrainian)

[Google Scholar]

27. Suez J., Korem T., Zeevi D. et al. Artificial sweeteners induce glucose intolerance by altering the gut microbiota. Journal Nature, 2014; 514 (7521): 181-186.

[DOI: https://doi.org/10.1038/nature13793; Google Scholar ]

28. Suguru Fukumoto, Takayuki Toshimitsu, Shuji Matsuoka, Atsushi Maruyama, Kyoko Oh-oka, Takeyuki Takamura, Kayoko Ishimaru, Yoshiaki Fujii-Kuriyama, Shuji Ikegami, Hiroyuki Itou, Atsuhito Nakao. Identification of a probiotic bacteria-derived activator of the aryl hydrocarbon receptor that inhibits colitis. Journal of Immunology and Cell Biology, 2014; 92(5): 460-465. [DOI: 10.1038/icb.2014.2; PMID: 24518984; Google Scholar]

29. Vazquez-Gutierrez P., Lacroix Ch., Jaeggi T., Zeder Ch., Bruce Zimmerman M., Chassard Ch. Bifidobacteria strains isolated from stools of iron deficient infants can efficiently sequester iron. BMC Microbiol., 2015; 15 (3): 1-10.

[DOI: 10.1186/s12866-014-0334-z; PMID:25591860 PMCID:pmc4320568; Google Scholar].

30. Woodcock M., Hollands W., Konic-Ristic A., Glibetic M., Boyko N., Kocaoglu B., Kroon P. Bioactive-rich extracts of persimmon but not nettle, Sideritis, dill or kale, increase enos activation and NO bioavailability and decrease endothelin-1 secretion by human vascular endothelial cells. J. Sci Food Agric., 2013; 93(14): 3574-80.

[DOI: https://doi.org/10.1002/jsfa.6251; PMID:23744813; Google Scholar]

\title{
НОВИЙ ФУНКЦІОНАЛЬНИЙ ХАРЧОВИЙ ПРОДУКТ ДЛЯ ЗАПОБІГАННЯ НЕ КОМУНІКАЦІЙНИМ ЗАХВОРЮВАННЯМ
}

\author{
В. В. Баті, Н. В. Бойко \\ Ужгородський національний університет \\ пл. Народна, 1, Ужгород 88000, Ukraine \\ e-mail:victoria.bati@uzhnu.edu.ua
}

Робота присвячена висвітленню реалізованих нами нових підходів у конструюванні функціональних продуктів харчування (ФПХ). На нашу думку, необхідною вимогою для конструювання таких нових ФПХ $є$ використання секвенованих мікроорганізмів із (клінічно) доведеними корисними біологічними властивостями (як пробіотичних компонентів чи мікробних заквасок, стартерів бродіння) і їстівних

ISSN 1996-4536 (print) • ISSN 2311-0783 (on-line) • Біологічні Студії / Studia Biologica • 2019 • Том 13/№1 • С. 71-84 
рослин, зокрема, ягід, які у свою чергу, є джерелом пребіотичних та біологічно активних речовин, вміст яких значною мірою залежить від умов культивування і способів технологічної обробки їжі.

Нами розроблено і запропоновано для виробництва ФПХ із очікуваними (прогностичними, наперед заданими) специфічними властивостями. Це кисломолочний напій, який складається із попередньо відібраних нами за біологічними властивостями встановленими in vitro та in vivo $[3,4]$ пробіотичної композиції авторських штамів мікроорганізмів Lactobacillus casei ATCC 27139 Lactobacillus plantarum JCM 1149, L. casei MGB63-1, L. plantarum та пребіотичної складової, представленої екстрактами (свіжовитиснений сік) ягід аличі, чорниці, гранату, хурми та кизилу. Ці рослинні екстракти (ягоди) багаті на біологічно активні речовини (БАР) і характеризуються здатністю спрямовано модулювати мікробіоценоз кишечника людини, зумовлюючи його корекцію у бік зменшення патогенних та умовно-патогенних і зростання корисних мікроорганізмів, антиоксидантними та протизапальними властивостями $[13,26]$.

Функціональний продукт має антибактеріальну активність щодо збудників кишкових інфекцій - Escherichia coli enteropathogenic (EPEC), Salmonella enterica підвид еnterica серовар Enteritidis (S. enteritidis), Shigella dysenteriae, до повного пригнічення їхнього росту через 72 год сумісного культивування. Також встановлено суттєву інгібуючу активність кисломолочного напою з екстрактом чорниці стосовно низки умовно-патогенних мікроорганізмів, таких як Morganella morganii, Staphylococcus aureus, метицилін-резистентний S. aureus (MRSA), Enterobacter cloacae. Таку ж саму дію було відмічено стосовно колекційного штаму E. coli ATCC 25922. Кисломолочний напій з аличею показав антибактеріальну дію стосовно штамів мікроорганізмів: E. coli ATCC 25922, EPEC, S. aureus, MRSA, S. Enteritidis, S. dysenteriae, Pseudomonas aeruginosa, Enterobacter cloacae. Кисломолочний продукт із чорницею пригнічував: P. aeruginosa, M. morganii, Listeria monocytogenes, S. enteritidis, S. dysenteriae, S. aureus, E. coli ATCC 25922, EPEC, MRSA, а також і коменсальні штами E. coli 058 та E. coli Schaedler's. Досліджено, що пригнічувальна дія кисломолочного продукту збільшилася із додаванням нативних екстрактів (чорниці/аличі/кропу/гранату). Алича та гранат мали більшу антагоністичну дію стосовно Klebsiella pneumonia і K. охуtoca. Водночас ФХП нового покоління стимулював ріст представників корисної мікробіоти.

Ключові слова: функціональний продукт; персоніфікований підхід; кишкова мікробіота; антимікробна активність; протизапальна активність; рослинні екстракти; пробіотики

Одержано: 05.04.2019

ISSN 1996-4536 (print) • ISSN 2311-0783 (on-line) • Біологічні Студії / Studia Biologica • 2019 • Том 13/№1 • C. 71-84 